\title{
Contamination of agricultural soil by arsenic containing irrigation water in Bangladesh: overview of status and a proposal for novel biological remediation
}

\author{
S. M. A. Islam ${ }^{1}$, K. Fukushi ${ }^{2} \&$ K. Yamamoto $^{3}$ \\ ${ }^{1}$ Department of Civil Engineering, \\ Dhaka University of Engineering and Technology, Bangladesh \\ ${ }^{2}$ Integreted Research System for Sustainability Science, \\ The University of Tokyo, Japan \\ ${ }^{3}$ Environmental Science Center, The University of Tokyo, Japan
}

\begin{abstract}
Arsenic toxicity in the groundwater of Bangladesh poses a serious threat to public health. More than 35 million people are consuming arsenic-polluted groundwater there. So far, a lot of effort has been made to find safe drinking water but no suitable solution has yet been established, while continued cropping with arsenic contaminated irrigation water increases the extent of contamination in agricultural land. The objective of this paper is to review information on the arsenic concentration in the agricultural soil of Bangladesh irrigated with arsenic-contaminated water. In addition, this study overviews the literature, which focus on the biological remediation of arsenic from soil. Arsenic as high as $10 \mathrm{~kg} / \mathrm{ha}$ per year is cycled through irrigated water and deposited on surface soil of Bangladesh, which results in its cumulative accumulation. It was observed to be as high as $83 \mathrm{mgAs} / \mathrm{kg}$ arsenic in the topsoil of irrigated agricultural land whereas in non-irrigated land arsenic was reported as 3-9 mgAs $/ \mathrm{kg}$. Considering the increasing trend of arsenic concentration in soil, it is necessary to establish some procedure for arsenic cleanup from soil. Biological cleanup could be a feasible solution for a developing country like Bangladesh. The feasibility of biological removal of arsenic from soil has been established in one study.

Keywords: arsenic concentration, agricultural land soil, rice plant, biological removal of arsenic, biological gasification of arsenic, soil column.
\end{abstract}




\section{Introduction}

Arsenic is a ubiquitous element and is assumed to be the $20^{\text {th }}$ most abundant element in the biosphere $[1,2]$. It is mostly naturally occurring and is mainly distributed in the environment as a consequence of weathering of rocks, volcanic activity, evaporation of water, anthropogenic input and biological activity [3]. Being a metalloid arsenic can present in soil, water, air and all living matter in any of the form of solid, liquid and gas. Arsenic, primarily in the inorganic form, is present in the earth's crust at an average of $2-5 \mathrm{mg} / \mathrm{kg}$ [4]. However, arsenic contamination has become a common problem in many parts of the world. Arsenic leaching has occurred from mine tailings in Australia, Canada, Japan, Mexico, Thailand, the United Kingdom and the United States. Arsenic contamination in natural aquifers has occurred in Argentina, Bangladesh, Cambodia, Chile, China, Ghana, Hungary, India, Mexico, Nepal, New Zealand, the Philippines, Taiwan, the United States and Vietnam [5].

Arsenic pollution has occurred most severely in Bangladesh and India (West Bengal). It is estimated that more than 35 million people are consuming arsenicpolluted ground water alone in Bangladesh where underground water is used mainly for drinking and cooking $[5,17]$. So far, lot of effort has been devoted to find safe drinking water there but no suitable measure has been established yet. In addition to the drinking water problem, continued irrigation with arseniccontaminated water increases the extent of arsenic contamination in agricultural land soil in Bangladesh [6-9]. Objective of this paper is to review information on the arsenic concentration in soil of Bangladesh, where arsenic-contaminated water is used for irrigation and also to provide information on subsequent effect on plant growing on contaminated soil. In addition, this study overviews the literatures, which focus on the biological remediation of arsenic from soil and proposes a novel biological remediation process for soil cleanup.

\section{Arsenic pollution in Bangladesh: overview of status}

\subsection{Heath effect of arsenic and its major exposure pathway to human in affected area}

Like other creatures, arsenic is toxic to human. The mode of toxicity depends on the chemical form of arsenic and concentration and duration of exposure. Inorganic forms of arsenic like arsenate and arsenite, are usually more toxic than those of organic forms. Arsenate, a molecular analog of phosphate, inhibits oxidative phosphorylation and inactivates life's main energy-generation system. Arsenite is even more broadly toxic as it binds to sulfhydryl groups and impairs the function of many proteins [10]. Acute exposure of arsenic is lethal to body depending on exposure time and concentration. Chronic arsenic poisoning can cause many serious health effects such as melanosis (hyperpigmentation or dark spots and hypopigmentation or white spots), hyperkeratosis (hardened skin), restrictive lung disease, peripheral vascular disease (blackfoot disease), gangrene, diabetes mellitus, hypertension, and ischaemic heart disease $[5,12]$. It is recognized that chronic consumption of arsenic, even at a low level, can cause 
carcinogenesis [2]. Malnutrition and poor socio-conomic conditions intensify the hazards of arsenic toxicity [13].

Human beings can be exposed to arsenic in many different ways: mainly by ingestion of contaminated water and food and by inhalation of metal-containing dust. As in arsenic polluted areas, arsenic-contaminated groundwater is used for drinking, cooking and irrigation, direct ingestion of drinking water, as well as cooking and soil-crop-food via food chain transfer may be the major exposure pathways of arsenic [15].

\subsection{Arsenic concentration in groundwater of Bangladesh}

From arsenic surveys conducted by different organizations in 60 districts out of 64 administrative districts of Bangladesh, it is observed that many tube wells of shallow depth (less than $100 \mathrm{~m}$ ) exceed the arsenic concentration level of $0.05 \mathrm{mg} / \mathrm{l}$ (Bangladesh Standard for arsenic in drinking water) in almost all 60 districts $[12,16]$. In a study of arsenic survey conducted by BGS/DPHE [16] in 60 districts observed that about $61 \%$ of samples exceed $0.01 \mathrm{mg} / \mathrm{l}$ (WHO Guideline for arsenic concentration in drinking water), about $45 \%$ samples exceed $0.05 \mathrm{mg} / \mathrm{l}$, and $2 \%$ exceed $1 \mathrm{mg} / \mathrm{l}$ of arsenic concentration in shallow tubewell among 9089 samples [13, 16]. The latest statistics on the arsenic contamination in groundwater of Bangladesh are presented in table 1 by summarizing different literature $[12,13,16]$.

Table 1: Latest statistics on arsenic concentration in groundwater of Bangladesh $[12,13,16]$.

\begin{tabular}{|l|c|}
\hline Total area in Bangladesh $\left(\mathrm{km}^{2}\right)$ & 147570 \\
\hline Total population (million) & 128 \\
\hline Total number of administrative districts & 64 \\
\hline Total number of districts surveyed & 60 \\
\hline Total number of districts where arsenic concentration exceeds $0.01 \mathrm{mg} / \mathrm{l}$ & 52 \\
\hline Total number of districts where arsenic concentration exceeds $0.05 \mathrm{mg} / \mathrm{l}$ & 41 \\
\hline Total area where arsenic concentration exceeds $0.05 \mathrm{mg} / \mathrm{l}\left(\mathrm{km}{ }^{2}\right)$ & 89186 \\
\hline Total population where arsenic concentration exceeds $0.05 \mathrm{mg} / \mathrm{l}(\mathrm{million})$ & 85 \\
\hline Median value of arsenic concentration observed in tested samples $(\mathrm{mg} / \mathrm{l})$ & 0.0108 \\
\hline Maximum arsenic concentration observed in tested samples $(\mathrm{mg} / \mathrm{l})$ & 1.67 \\
\hline
\end{tabular}

\subsection{Arsenic concentration in soil of Bangladesh}

Due to the scarcity of water in dry season, groundwater is very necessary for irrigation especially in the northern part of Bangladesh. It is more likely that the last 30 years of irrigation have led to diffuse contamination of land throughout the districts depending on arsenic-contaminated groundwater [15]. A preliminary estimate of arsenic deposition on irrigated agricultural land has been conducted by DPHE/BGS [16] shows that a large amount of arsenic as high as $10 \mathrm{~kg} / \mathrm{ha}$ per year is cycled through irrigated water and deposited on surface soil of Bangladesh. A large portion of this arsenic remains in soil due to its affinity for iron, manganese, aluminum and other minerals in soil and not likely to be 
washed out by flood or rainwater, which results in a cumulative accumulation of arsenic in soil [8].

Some studies reported arsenic concentration in uncontaminated land of Bangladesh, which varies from 3-9 mgAs/ $\mathrm{kg}[6,7]$. On the other hand, elevated arsenic concentrations were observed in many studies in agricultural land soil irrigated with arsenic-contaminated water, which is in some cases found about 10-20 times higher than arsenic concentration in non-irrigated land. Ullah [6] reported arsenic concentration in top agricultural land soil (up to 0-30 cm depth) up to $83 \mathrm{mgAs} / \mathrm{kg}$, Islam et al [18] up to $80.9 \mathrm{mgAs} / \mathrm{kg}$, Alam and Sattar [7] up to $57 \mathrm{mgAs} / \mathrm{kg}$ of soil for samples collected from different districts of Bangladesh. The reported arsenic concentration for agricultural land soil in different district of Bangladesh is summarized in table 2 .

It is obvious from the result that high arsenic concentration in source tube well supplying the irrigation water is mainly responsible for accumulation of high arsenic content in soil. However, no significant correlation between waterAs and soil-As was observed by Islam et al [18] and Huq et al [14] as shown in fig.1. In contrast, some sort of positive relation was observed by some other studies $[5,19]$. However, the arsenic accumulation in agricultural soil not only depends on the source well concentration but also depends on soil properties, especially the clay content (permeability), organic content (biological transformation), etc.

Arsenic concentration in agricultural soil is usually found higher for those source tube wells, which have been operated for longer period of time. Regression of soil arsenic levels with tube-well age was found significant [19]. Agricultural soil arsenic concentration varies with depth of soil. Ali et al [8] obtained high arsenic concentration in topsoil $(0-15 \mathrm{~cm})$ with a decreasing profile along depth. Soil arsenic concentration in agricultural field also varies along with crop season. Higher arsenic concentration is usually observed at the end of irrigation period than the beginning $[8,9]$. Lowest concentration is usually obtained after flood. It can be inferred that the accumulated arsenic during irrigation period is partially washed by rain and flood water [8].

\subsection{Arsenic concentration in rice, vegetables and other plants}

It can be accounted that higher arsenic concentration in irrigation water and soil results in higher concentration of arsenic in crops. Arsenic accumulation was observed in roots, stem and leaves of rice plants $[5,8,19-22]$. Table 3 summarises the arsenic concentration level in rice grains observed in different districts of Bangladesh by some studies. The average arsenic concentration observed in rice grains in different studies is lower than the food hygiene concentration limit of $1 \mathrm{mg} / \mathrm{kg}$ [5]. The different varieties of rice tested for accumulation of arsenic by different studies are khatobada, paijam, swarna, gocha, kalia, swarna and different types of BR. Among them BR11 from Naogaon was found to have high arsenic concentration of $1.84 \mathrm{mg} / \mathrm{kg}$ [19]. Arsenic concentration observed in much higher range in roots and straw than leaves and rice grains $[5,8]$. The high arsenic concentrations in straw may have 


\begin{tabular}{|c|c|c|c|c|c|c|c|c|c|c|c|c|c|c|c|c|c|c|c|c|}
\hline & & & & & & & & & & & & & & & & & & & & \\
\hline & & & & & & & & & & & & & & & & & & & & \\
\hline $\overrightarrow{\underline{\vec{V}}}$ & 2 & 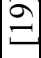 & 2 & 2 & ב & 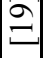 & 2 & 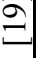 & $\Xi$ & $\stackrel{2}{\beth}$ & 2 & 20 & $2 \approx$ & 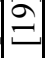 & 2 & 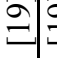 & $\stackrel{0}{2}$ & 270 & 20 & 19 \\
\hline 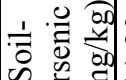 & & & $\begin{array}{l}\text { 이 } \\
\dot{+} \\
\dot{+}\end{array}$ & $\left|\begin{array}{l}0 \\
n \\
0\end{array}\right|$ & 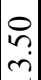 & 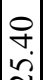 & & $\begin{array}{l}0 \\
m \\
m\end{array}$ & & $\begin{array}{l}\text { 이 } \\
\sim \\
\end{array}$ & & 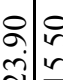 & 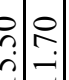 & $\mid \begin{array}{l}0 \\
8 \\
9\end{array}$ & @. & & & & on & $\begin{array}{l}? \\
? \\
\end{array}$ \\
\hline
\end{tabular}

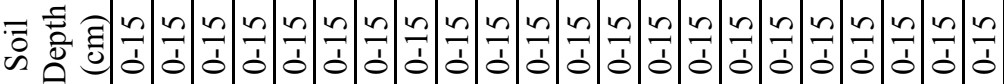

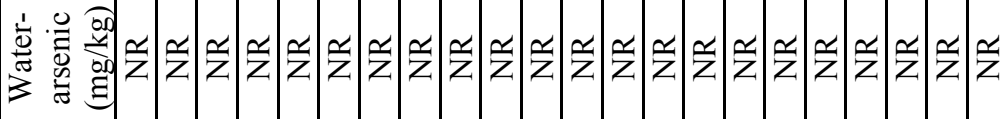

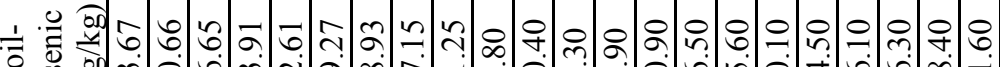
भ

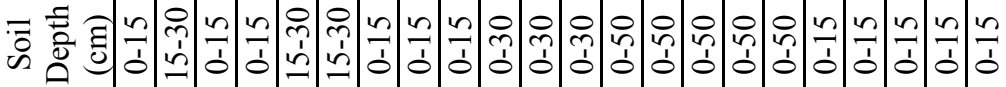
. $\infty$ 它

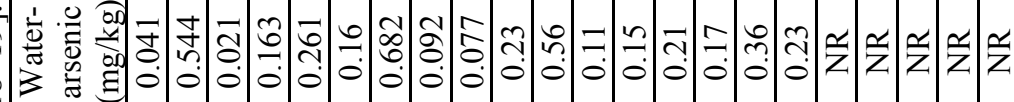

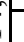

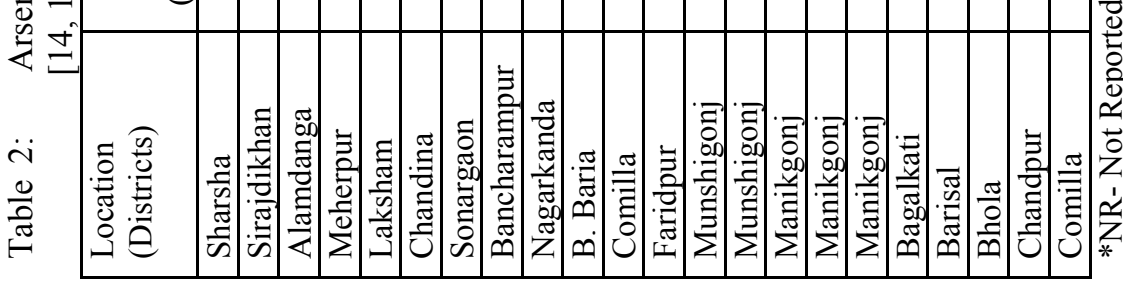




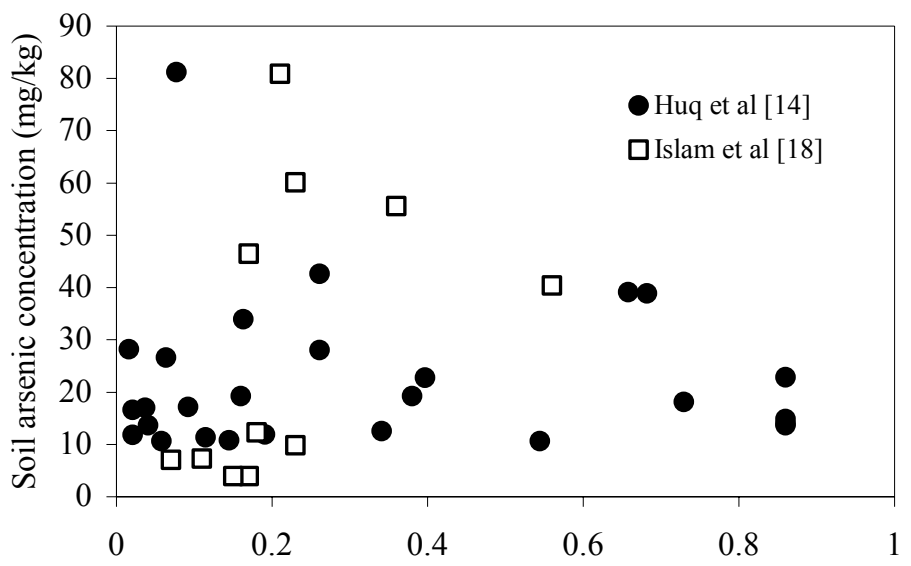

Water arsenic concentration $(\mathrm{mg} / \mathrm{kg}$ )

Figure 1: Correlation between arsenic concentration in agricultural soils and source tube wells supplying the irrigation water obtained in different studies.

adverse health effects on the cattle and thus can increase chance of arsenic exposure in humans via the plant-animal-human pathway [20].

Vegetables and other plants growing on arsenic contaminated soil exhibit arsenic accumulation [5]. Table 4 summarizes the arsenic concentration level in vegetables and other plant varieties in some districts of Bangladesh reported by different studies. Among the vegetables korola (Momordica charantia), gourd, potol (Trichosanthesdioeca), okra/vindi/dharosh (Hibiscus esculentus), data stem (Amaranthus lividus), etc. were not found to contain high amounts of arsenic [5]. It was observed that plant uptake of arsenic is highly variable among plant species and is also influenced by soil characteristics, soil fertility, and concentration and chemical forms of arsenic in soil [8].

\section{Perspective of biological removal of arsenic from soil: a novel approach for permanent clean up}

Biological transformation of arsenic plays an important role in the distribution and cycling of arsenic in arsenic-rich environment. Microbes are able to metabolize inorganic arsenic to less toxic both volatile and nonvolatile organic species such as monomethylarsine (MMA), dimethylarsine (DMA), and trimethylarsine (TMA) and non-volatile species such as methylarsonic acid, dimethylarsinic acid, and trimethylarsenic oxide. Arsenic biomethylation can be considered as a detoxification of arsenic in the environment because the toxicity of organic arsenic is much less than that of inorganic arsenic [11]. Production of volatile methylated species has further importance in the removal of arsenic from 
environmental samples (soil/sediment) and biosolids [24]. In soil, biological removal of arsenic can be achieved by 1) reduction of arsenate to mobile arsenite and subsequent collection and treatment of water, 2) biosorption and bioaccumulation 3) biogasification. The last one is advantageous as it is a phase change of arsenic and can be involved in the removal of arsenic from soil as it is basically a natural process.

Table 3: Arsenic concentration level in rice plants observed in different districts of Bangladesh reported in different literature.

\begin{tabular}{|l|l|l|l|l|c|}
\hline Location (District) & $\begin{array}{l}\text { Area } \\
\text { Survey }\end{array}$ & $\begin{array}{l}\text { Arsenic } \\
\text { conc. } \\
\text { range } \\
(\mathrm{mg} / \mathrm{kg})\end{array}$ & $\begin{array}{l}\text { Mean } \\
\text { arsenic } \\
\text { conc. } \\
(\mathrm{mg} / \mathrm{kg})\end{array}$ & $\begin{array}{l}\text { No. } \\
\text { of } \\
\text { samp. } \\
(\mathrm{n})\end{array}$ & Ref \\
\hline Rajshahi & District & $0.03-0.34$ & 0.10 & 24 & {$[21]$} \\
\hline Rajshahi & Market & $0.03-0.28$ & 0.11 & 17 & {$[21]$} \\
\hline Pabna & Cooked food & $0.11-0.36$ & 0.24 & 4 & {$[14]$} \\
\hline Chadpur, Jamalpur & Random & $0.04-0.27$ & 0.14 & 10 & {$[5]$} \\
\hline Jessore & Village & $0.11-0.94$ & 0.28 & 21 & {$[21]$} \\
\hline Nawabganj & Boro, District & $0.01-0.99$ & 0.33 & 8 & {$[23]$} \\
\hline Sonargaon & Field & $0.05-1.23$ & 0.46 & 12 & {$[8]$} \\
\hline Srinagar & Random & $0.09-1.84$ & 0.5 & 13 & {$[19]$} \\
\hline Dinajpur & Field & - & 0.54 & 9 & {$[8]$} \\
\hline Gopalganj & Boro, district & $0.01-1.18$ & 0.57 & 6 & {$[23]$} \\
\hline Rajbari & Boro, district & $0.05-2.05$ & 0.76 & 8 & {$[23]$} \\
\hline Faridpur & Boro, District & $0.21-1.5$ & 0.95 & 7 & {$[23]$} \\
\hline
\end{tabular}

Table 4: Arsenic concentration level in rice and other plant verities in Bangladesh reported in different studies.

\begin{tabular}{|l|c|c|c|}
\hline Name of verity & $\begin{array}{c}\text { Arsenic } \\
\text { conc. } \\
(\mathrm{mg} / \mathrm{kg})\end{array}$ & $\begin{array}{c}\text { No. } \\
\text { of } \\
\text { samp. }\end{array}$ & Ref. \\
\hline Arum leaves (Colocasia antiquorum) & $0.09-3.99$ & 9 & {$[5]$} \\
\hline Potatoes (Solanum tuberosum) & $0.07-1.39$ & 5 & {$[5]$} \\
\hline Kalmi sak (Ipomoea reptans) & $0.1-1.53$ & 6 & {$[5]$} \\
\hline Ghotkol (Typhonium trilobatum) & 0.45 & $\mathrm{NR}$ & {$[15]$} \\
\hline Taro/Kachu lati (Colocasia esculenta) & 0.44 & $\mathrm{NR}$ & {$[15]$} \\
\hline $\begin{array}{l}\text { Snake gourd/Chichinga (Trichosanthes } \\
\text { anguina) }\end{array}$ & 0.49 & $\mathrm{NR}$ & {$[15]$} \\
\hline Brinjal (Solanum melongena) ground leaf (Lagenaria & 0.20 & $\mathrm{NR}$ & {$[15]$} \\
\hline $\begin{array}{l}\text { Lau sak/Bottle NR } \\
\text { siceraria) }\end{array}$ & 0.30 & NR] \\
\hline Green papaya (Carica papaya) & 0.45 & $\mathrm{NR}$ & {$[15]$} \\
\hline
\end{tabular}

*NR- Not Reported 
Though biological gasification of arsenic was evidenced earlier, Islam et al $[9,18]$ was first started working on biological gasification of arsenic as an engineering process for arsenic removal from soil/solids. Islam et al [9, 18] observed microbial volatilization of arsenic as MMA, TMA and arsine from different soil samples collected from agricultural soil of Bangladesh cultured in batch under anaerobic conditions at $37^{\circ} \mathrm{C}$ using substrate as acetate and formate. The observed results positively indicate the possibility of using biogasification of arsenic in bioremediation from soil.

In order to observe arsenic gasification in original soil for application of arsenic bioremediation, Islam [24] further conducted soil column test where native soil microbial growth was enhanced by supplying substrate favorable for methanogenic growth. In that study microbial gasification was observed from existing arsenic concentration in the soil, no external arsenic was added. Five soil columns were run with triplicate as sample and two as control. The columns were filled with soil of around 300 grams under anaerobic condition and were incubated at room temperature $\left(25 \pm 3^{\circ} \mathrm{C}\right)$. The steady state rate of gasification was observed after 90 days of operation as $0.4 \mu \mathrm{gAs} / \mathrm{d}$, which is very low. However, the results established the feasibility of biological removal of arsenic from soil while it requires longer time for total clean up. Islam [24] further achieved bioaugmentation in the column by adding microorganisms grown in cow dung-seeded reactor, which were previously acclimated to arsenic. It was observed that gasification rate of arsenic was rapidly increased after addition of new microrganisms even up to 8 times. This observation undoubtedly established the possibility of arsenic clean up from the contaminated soil of Bangladesh within a reasonable time.

\section{Conclusion}

This study summarized the present status of agricultural soil arsenic concentrations in Bangladesh, which are irrigated with arsenic-contaminated water. There is no regulatory guideline for soil or plant arsenic concentration in Bangladesh. Some developed countries provide such guideline, for example, the regulatory limit of arsenic for agricultural soil is set for environmental health investigation in Australia is $20 \mathrm{mgAs} / \mathrm{kg}$. This suggests that in case of exceeding this level requires soil clean up [25]. Considering increasing concentration in agricultural soil and its subsequent effect on plants, establishment of such a guideline is necessary and as a result some soil may require cleanup of arsenic. Biological cleanup could be fruitful solution for a developing country like Bangladesh. The feasibility of biological removal of arsenic from soil has already been established by Islam [24]. The application of biological removal as a novel process can be introduced after investigation of the fate of volatile arsenic compound in the environment, which is hitherto unknown. 


\section{References}

[1] Woolson, E. A., Generation of alkylarsines from soil. Weed Science, 25, pp. 412-416, 1977.

[2] Mandal, K.M. \& Suzuki, K.T., Arsenic round the world: a review. Talanta 58, pp. 241-235, 2002

[3] Cullen, W.R. \& Reimer, K. J., Arsenic speciation in the environment. Chemical Reviews, 89, pp. 713-764, 1989.

[4] Tamaki, S. \& Frankenberger, W.T., Environmental Biochemistry of Arsenic. Reviews of Environmental Contamination and Toxicology, 124, pp. 79-110, 1992.

[5] Das, H. K., Mitra, A. K., Sengupta, P. K., Hossain, A., Islam, F. \& Rabbani, G. H. Arsenic concentrations in rice, vegetables, and fish in Bangladesh: a preliminary study. Environment International, 30, pp. 383387, 2004.

[6] Ullah, S.M., Arsenic Contamination of Groundwater and Irrigated Soils in Bangladesh, Proc. of the International Conference on Arsenic Pollution on Groundwater in Bangladesh: Causes, Effects and Remedies, Dhaka, Bangladesh, 1998.

[7] Alam, M.B. \& Satter M.A., Assessment of Arsenic Contamination in Soils and Waters in Some areas of Bangladesh. Water Science Technology, 42 (7-8), pp. 185-192, 2000.

[8] Ali M.A., Badruzzaman A.B.M., Jalil M.A., Hossain M.D., Ahmed M.F., Masud A.A., Kamruzzaman M. \& Rahman M.A., Arsenic in Plant-Soil Environment in Bangladesh. Fate of Arsenic in the Environment, eds. M. F. Ahmed, M. A. Ali \& Z. Adeel, BUET-UNU, Dhaka, pp 85-112, 2003.

[9] Islam, S.M.A, Fukushi, K. \& Yamamoto, K., Severity of arsenic concentration in soil and arsenic-rich sludge of Bangladesh and potential of their biological removal: a novel approach for tropical region. Proc. of the Second International Symposium on Southeast Asian Water Environment, Hanoi, Vietnam, 2004.

[10] Oremland, R.S. \& Stolz, J.F., The ecology of arsenic. Science, 300, pp 939-944, 2003

[11] Kaise, T., Yamauchi, H., Horiguchi, Y., Tani, T., Watanabe, S., Hirayama, T. \& Fukui, S., A comparative study on acute toxicity of methylarsonic acid, dimethylarsinic acid and trimethylarsine oxide in mice. Applied Organometallic Chemistry, 3, pp. 273-277, 1989.

[12] Rahman, M.H., Rahman, M.M., Watanabe, C. \& Yamamoto., K., (2002). Arsenic contamination of groundwater in Bangladesh and its remedial measures, Arsenic Contamination in Groundwater -Technical and Policy Dimensions. Proc. on the UNU-NIES International Workshop, Tokyo. United Nations University (UNU) and Japan National Institute for Environmental Studies (NIES), Tokyo.

[13] Hossain, M.F., Arsenic contamination in Bangladesh-An overview. Agriculture Ecosystem \& Environment, in press, 2005. 
[14] Huq, S.M.I., Rahman, A., Sultana, N. \& Naidu R., Extent and Severity of Arsenic Contamination in Soil of Bangladesh. Fate of Arsenic in the Environment, eds. M. F. Ahmed, M. A. Ali \& Z. Adeel, BUET-UNU, , Dhaka, pp 69-84, 2003.

[15] Alam, M.G.M., Snow, E.T. \& Tanaka, A., Arsenic and heavy metal contamination of vegetables grown in Samta village, Bangladesh. The Science of the Total Environment, 308, pp. 83-96, 2003.

[16] BGS/DPHE, Groundwater studies for arsenic contamination in Bangladesh, Final Report, Summary, Department of Public Health and Engineering, Government of Bangladesh, DFID, British Geological Survey, Dhaka, Bangladesh, 2000.

[17] Rabbani, G.H., Chowdhury, A.K., Shaha, S.K. \& Nasir, M. Mass arsenic poisoning of ground water in Bangladesh. Proc. of the Global Health Council Annual Conference, Washington DC, 2002.

[18] Islam, S.M.A, Fukushi, K. and Yamamoto, K., Bioreduction and biomethylation of arsenic in soil of Bangladesh: novel process for permanent removal of arsenic. Proc. of the 1st IWA-ASPIRE Conference \& Exhibition, Singapore, 2005.

[19] Meharg, A.A. \& Rahman, M.M., Arsenic contamination of Bangladesh paddy field soils: implications for rice contribution to arsenic consumption. Environmental Science \& Technology, 37, pp. 229-234, 2003.

[20] Abedin, M.J., Cresser, M.S., Meharg, A.A., Feldmann, J. \& CotterHowells, J., Arsenic Accumulation and Metabolism in Rice. Environmental Science Technology, 36(5), pp. 962-968, 2002.

[21] Hironaka, H. \& Ahmed, S.A., Arsenic Concentration of Rice in Bangladesh. Fate of Arsenic in the Environment, eds. M. F. Ahmed, M. A. Ali \& Z. Adeel, BUET-UNU, Dhaka, pp 69-84, 2003

[22] Williams, P.N., Price, A.H., Raab, A., Hossain, S.A., Feldmann, J., \& Meharg, A.A., Variation in arsenic speciation and concentration in paddy rice related to dietary exposure. Environmental Science \& Technology, 39, pp. 5531-5540, 2005.

[23] Islam, M. R., Jahiruddin, M. \& Islam, S., Assessment of arsenic in the water-soil-plant systems in gangetic flood plains of Bangladesh. Asian Journal of Plant Science, 3, pp. 489-493, 2004.

[24] Islam S.M.A., (2005) Gasification of arsenic from contaminated solids by anaerobic microorganisms. PhD Dissertation, The University of Tokyo, Tokyo, Japan.

[25] O’Neil, P., Arsenic. Heavy Metals in Soils, ed. B.J. Alloway, John Wiley \& Sons, New York, 1990. 